\title{
Fibrosis indexes in adolescents with juvenile idiopathic arthritis treated with methotrexate
}

\author{
Wskaźniki włóknienia wątroby u młodzieży z młodzieńczym idiopatycznym zapaleniem stawów \\ leczonej metotreksatem
}

\author{
1 Department of Adolescence Medicine, Kharkiv Medical Academy of Postgraduate Education, Kharkiv, Ukraine \\ ${ }^{2}$ Department of Paediatrics, V. N. Karazin Kharkiv National University, Kharkiv, Ukraine \\ ${ }^{3}$ Central Scientific Laboratory, Kharkiv Medical Academy of Postgraduate Education, Kharkiv, Ukraine \\ ${ }^{4}$ Department of Paediatrics 2, V. N. Karazin Kharkiv National University, Kharkiv, Ukraine \\ Correspondence: Olga Pavlova, Department of Adolescence Medicine, Kharkiv Medical Academy of Postgraduate Education, Amosova street 58, 61176 Ukraine, Kharkiv, \\ tel.: +380676887202, e-mail: ospavlova@mail.ua
}

\begin{abstract}
Juvenile idiopathic arthritis is the most common form of arthritis in children and adolescents. Methotrexate is the mainstay of juvenile idiopathic arthritis treatment. Methotrexate is well known to cause serum aminotransferase elevations, and longterm therapy has been linked to the development of fatty liver disease, fibrosis and even cirrhosis. The aim of the study was to assess non-invasive liver fibrosis indexes in adolescents with juvenile idiopathic arthritis treated with methotrexate. Materials and methods: A total of 68 children with juvenile idiopathic arthritis were enrolled in the study. A total of 68 children - 25 boys (36.8\%) and 43 girls (63.2\%) - were examined. The children were divided into four groups based on the methotrexate cumulative dose. The following data were analysed: total bilirubin and its fractions, cholesterol, $\beta$-lipoproteins, aspartate transaminase, alanine aminotransferase. Fibrosis indexes, i.e. APRI, FIB-4 score, AAR, AARPRI, were studied. Results: When studying the dynamics of non-invasive indices, their heterogeneous nature and cumulative dose dependence are determined. Statistically significant changes in fibrosis indexes and biochemical parameters were observed when the children reached cumulative methotrexate doses of $1 \mathrm{~g}$ and $3 \mathrm{~g}$. Conclusions: It is possible to monitor carefully liver condition during the whole treatment and conduct a more in-depth examination only if it is necessary. Our data shows that the APRI index (AST to platelet ratio index) is most indicative.
\end{abstract}

Keywords: juvenile idiopathic arthritis, methotrexate, liver, APRI index

Streszczenie Młodzieńcze idiopatyczne zapalenie stawów to najczęstsza postać zapalenia stawów u dzieci i młodzieży. Podstawą leczenia młodzieńczego idiopatycznego zapalenia stawów pozostaje metotreksat. Wiadomo, że lek ten powoduje zwiększenie stężenia aminotransferaz w surowicy, a jego przedłużone stosowanie może być związane z rozwojem stłuszczenia, włóknienia, a nawet marskości wątroby. Celem pracy była ocena nieinwazyjnych wskaźników włóknienia wątroby u młodzieży z młodzieńczym idiopatycznym zapaleniem stawów leczonej metotreksatem. Materiał i metody: Do badania włączono łącznie 68 dzieci z młodzieńczym idiopatycznym zapaleniem stawów. Przebadano 68 pacjentów - 25 chłopców (36,8\%) i 43 dziewczynki (63,2\%). Na podstawie skumulowanej dawki metotreksatu dzieci podzielono na cztery grupy. Analizie poddano następujące parametry: stężenie bilirubiny całkowitej i jej frakcji, cholesterolu, $\beta$-lipoproteiny, transaminazy asparaginianowej i aminotransferazy alaninowej. Ponadto dokonano oceny wskaźników włóknienia wątroby, tj. APRI, FIB-4, AAR i AARPRI. Wyniki: Ocena dynamiki nieinwazyjnych wskaźników włóknienia wątroby ujawniła ich niejednorodny charakter i zależność od dawki skumulowanej. Statystycznie istotne zmiany wskaźników włóknienia i parametrów biochemicznych obserwowano po osiągnięciu przez dzieci skumulowanych dawek metotreksatu wynoszących 1 g i 3 g. Wnioski: Istnieje możliwość dokładniejszego monitorowania czynności wątroby podczas całego procesu leczenia, a także - kiedy jest to konieczne - przeprowadzenia pogłębionej diagnostyki. Z uzyskanych danych wynika, że wskaźnik APRI (stosunek aktywności aminotransferazy asparaginianowej do liczby płytek krwi) wykazuje największą użyteczność.

Słowa kluczowe: młodzieńcze idiopatyczne zapalenie stawów, metotreksat, wątroba, wskaźnik APRI 


\section{INTRODUCTION}

$\mathrm{J}$ uvenile idiopathic arthritis (JIA) is a heterogeneous group of conditions which encompasses all forms of arthritis of unknown aetiology lasting for at least 6 weeks and with onset before the age of 16 years $^{(1)}$. JIA is a diagnosis of exclusion, and remains the most common childhood rheumatic disease. The aetiology of JIA still remains unknown ${ }^{(2,3)}$. There were various classification criteria for determining certain clinical subgroups of JIA, which have changed somewhat in recent years. The new classification went through multiple revisions and is used in modern rheumatology $\mathrm{y}^{(4)}$. Non-steroidal anti-inflammatory drugs (NSAIDs), antimetabolics (methotrexate - MTX) and immunobiological therapy are used to treat JIA. Despite active discussion on the use of immunobiological therapy in the modern literature, the effectiveness of the traditional JIA treatment regimen using NSAIDs and MTX does not lose its importance. This was also confirmed by a recent large-scale study conducted in Canada, which analysed data from the last 5 years ${ }^{(5)}$.

Patients' response to MTX therapy has been repeatedly studied. However, the mechanisms of side effects and risk factors for JIA treatment with MTX have not been clearly established so far. In some cases, this affects treatment quality and patient's life, which can lead to drug discontinuation. However, determining the amount of MTX metabolites in the body is not an easy task. Plasma MTX concentrations rapidly fall below pharmacologically effective levels; therefore, they are not reliable for predicting the efficacy or MTX toxicity in patients with JIA ${ }^{(6-9)}$. MTX has been associated with a range of liverrelated adverse events ranging from asymptomatic transaminase elevations to fibrosis and fatal hepatic necrosis. Concern over potential liver toxicity has resulted in treatment avoidance, cessation, or recommendations for investigations which may be costly, invasive and unwarranted.

Non-invasive markers for the early detection of liver fibrosis and steatosis stay relevant ${ }^{(10)}$. The majority of present day studies report an approximate doubling of the relative risk of elevated transaminases in MTX-treated patients, but no increased risk of symptomatic or severe liver related adverse events. A lot of known and new markers of fibrosis, apoptosis and inflammation were discussed in diverse patients groups. There are clinical or biochemical markers and mathematical indexes created on their basis; as well as modern technologies, such as microarray methods, proteomics and glycomics ${ }^{(11)}$.

The importance of alanine aminotransferase (ALT) levels increasing in the JIA treatment with MTX do not have clear coverage in modern literature. There are studies in which it was highlighted that an increase in ALT level before treatment was a strong predictor of early and repeated increases in ALT level with further therapy. An individual approach to monitoring ALT level increasing during JIA therapy is recommended ${ }^{(12)}$. JIA patients with a high cumulative dose of MTX should be carefully monitored for liver fibrosis ${ }^{(13)}$. Liver fibrosis and steatosis indexes can be used to identify a group of children who need careful monitoring of the liver. However, the criteria for the appropriateness of using these indexes with JIA are still to be studied ${ }^{(14-18)}$. The use of fibrosis and steatosis indexes has been repeatedly studied. They were compared with liver elastography and morphological data ${ }^{(13,19,20)}$. Liver morphological studies are dangerous for children and cannot be performed in JIA patients. Liver elastography has been already carefully studied in patients with JIA treated with MTX $^{(21)}$. Elastography results were compared with a liver morphological examination ${ }^{(22)}$. MTX cumulative dose and elastography were also observed together ${ }^{(16,23)}$. A comparative analysis of elastography results and fibrosis indexes was performed ${ }^{(24)}$. The use of liver fibrosis indexes in the JIA treatment is still unclear. Thus, it is important to identify a cohort of patients for careful examination using mathematical indexes.

\section{AIM OF THE STUDY}

An assessment of the usefulness of non-invasive liver fibrosis indexes in MTX-treated adolescents with JIA.

\section{MATERIALS AND METHODS}

The study group comprised JIA patients, a total of 68 children - 25 boys (36.8\%) and 43 girls (63.2\%). The average age of patients was $13.3 \pm 0.3$ years. Children were treated for JIA at the Cardiac-Rheumatology Department, State Institution „Institute for the Protection of Children and Adolescents' Health under the Academy of Medical Sciences of Ukraine."

Inclusion criteria were boys and girls from 10 to 18 years old with JIA (with oligoarthritis and polyarthritis) treated with MTX or patients who were prescribed MTX, but had not received it before this study.

Exclusion criteria: children with chronic liver pathology, gastrointestinal, genetic and endocrine disorders, which occurred before JIA was diagnosed, children with uveitis. All examined patients had no viral hepatitis.

The diagnosis of JIA was established in accordance with the European Alliance of Associations for Rheumatology (EULAR) recommendations relevant at the time of the study. Treatment was carried out according to the same recommendations for all children. Informed consents were obtained from all patients.

This work complies with ethical standards (Kharkiv Medical Academy of Postgraduate Education Ethical committee No. 5 on $12^{\text {th }}$ of November 2019).

All adolescents underwent laboratory tests: a clinical blood test, liver tests [total bilirubin - $\mathrm{Bl}$ and its fractions $(\mu \mathrm{mol} / \mathrm{L})$, cholesterol $(\mathrm{mmol} / \mathrm{L}), \beta$-lipoproteins $(\mathrm{g} / \mathrm{L})$, aspartate transaminase (AST) $(\mathrm{U} / \mathrm{L})$, ALT $(\mathrm{U} / \mathrm{L})]$, hemorenal tests, acute phase indicators [C-reactive protein $(\mathrm{mg} / \mathrm{L})$, antistreptolysin $\mathrm{O}(\mathrm{U} / \mathrm{mL})]$, rheumatoid factor $(\mathrm{U} / \mathrm{mL})$, antinuclear antibodies (ANA) $(\mathrm{U} / \mathrm{mL})$. Abdominal ultrasound, joint ultrasound, electrocardiography and joint $\mathrm{X}$-ray were performed. 


\begin{tabular}{|c|c|c|c|c|c|c|}
\hline \multicolumn{2}{|r|}{ Patient's groups } & \multirow{2}{*}{$\begin{array}{c}\begin{array}{c}\text { Total bilirubin } \\
(\boldsymbol{\mu m o l} / \mathrm{L})\end{array} \\
15.6 \pm 1.09 \\
\end{array}$} & \multirow{2}{*}{$\begin{array}{c}\begin{array}{c}\text { Cholesterol } \\
\text { (mmol/L) }\end{array} \\
5.02 \pm 0.15\end{array}$} & \multirow{2}{*}{$\begin{array}{c}\boldsymbol{\beta} \text {-lipoproteins (g/L) } \\
8.48 \pm 0.36 \\
\end{array}$} & \multirow{2}{*}{$\begin{array}{c}\text { AST (U/L) } \\
25.1 \pm 2.25 \\
\end{array}$} & \multirow{2}{*}{$\begin{array}{c}\text { ALT (U/L) } \\
20.9 \pm 1.97 \\
\end{array}$} \\
\hline 1 & Did not receive MTX $(n=18)$ & & & & & \\
\hline 2 & MTX CD up to $1 \mathrm{~g}(n=15)$ & $14.9 \pm 0.92$ & $5.26 \pm 0.27$ & $8.14 \pm 0.58$ & $34.9 \pm 2.65$ & $30.1 \pm 2.75$ \\
\hline 3 & MTX CD 1-3g $(n=18)$ & $15.4 \pm 1.26$ & $5.06 \pm 0.20$ & $7.67 \pm 0.36$ & $30.5 \pm 2.84$ & $30.9 \pm 4.22$ \\
\hline 4 & MTX CD more than $3 \mathrm{~g}(n=17)$ & $17.8 \pm 1.71$ & $5.23 \pm 0.26$ & $8.46 \pm 0.71$ & $27.9 \pm 1.94$ & $28.4 \pm 3.89$ \\
\hline \multicolumn{2}{|r|}{ Norms } & Up to $20.5 \mu \mathrm{mol} / \mathrm{L}$ & $3.1-5.2 \mathrm{mmol} / \mathrm{L}$ & $3.5-6.6 \mathrm{~g} / \mathrm{L}$ & Up to $37 \mathrm{U} / \mathrm{L}$ & Up to $42 \mathrm{U} / \mathrm{L}$ \\
\hline
\end{tabular}

Tab. 1. Biochemical studies results in patients with JIA

Fibrosis indexes were calculated with Microsoft Excel.

- APRI - AST to platelet ratio index ${ }^{(25)}$ : [(AST/ULN AST) $\times 100] /$ platelets $\left(10^{9} / \mathrm{L}\right)$ ] [ULN - upper limit of normal]

- FIB-4 score - Fibrosis 4 Score ${ }^{(26)}$ : $($ age $\times$ AST $) /[$ platelets $\times(\operatorname{sqr}(\mathrm{ALT})]$

- AAR - AST to ALT Ratio ${ }^{(27)}:$ AST/ALT

- AARPRI - AAR/(platelet count $\left.\left(10^{9} / \mathrm{L}\right) / 150\right)^{(28)}$

Four groups of children were formed. Group 1 included children with JIA who had not received MTX yet $(n=18)$, group 2 included children who received MTX in a cumulative dose lower than $1 \mathrm{~g}(n=15)$, group 3 included children who had already received MTX from 1 to $3 \mathrm{~g}(n=18)$, and group 4 included children who received more than $3 \mathrm{~g}$ of $\operatorname{MTX}(n=17)$.

Statistical analysis was carried out with software package Statistica 6.0, in accordance with the generally accepted standards of mathematical statistics. Before statistical processing, all data were checked for normal distribution. One-way ANOVA was used to analyse differences between groups. LSD test was used to calculate the statistical significance. Differences were considered significant at $p<0.05$.

\section{RESULTS}

The assessments were conducted in a group of 68 adolescences with JIA. The results of blood biochemical studies are presented in Tab. 1 .

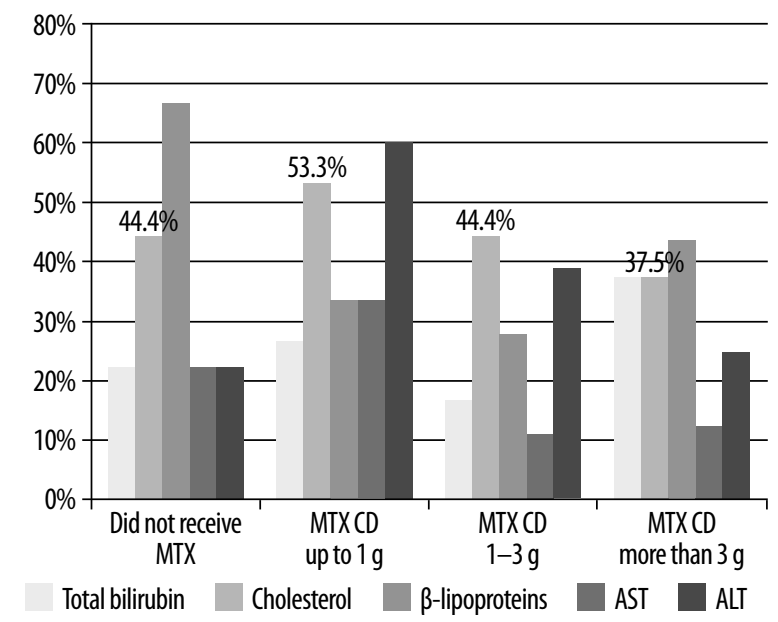

Fig. 1. Biochemical parameters for groups
It was found that the levels of Bl, AST, ALT do not differ from the laboratory norm. Average cholesterol levels were almost the same in all groups, and were slightly increased in the group of adolescents who received MTX $<1 \mathrm{~g}$ and those who received MTX $>3 \mathrm{~g}$. The mean values of $\beta$-lipoproteins in all groups of adolescents were increased. $\mathrm{Bl}$, cholesterol, AST and ALT were compared in accordance with their average values (Fig. 1). The results were compared with the average values for patients depending on sex and age. In group 1 , an increase was observed $(\mathrm{Bl}-22.2 \%$, cholesterol $-44.4 \%$, AST $-22.2 \%$, ALT - 22.2\%). The same indicators were more increased in children with MTX cumulative dose $<1 \mathrm{~g}(\mathrm{Bl}-26.7 \%$, cholesterol - 53.3\%, AST $33.3 \%$, ALT - 60\%). In the next group of children, with MTX cumulative dose from 1 to $3 \mathrm{~g}$, all four parameters were decreased (Bl - 16.7\%, cholesterol - 44.4\%, AST - 11.1\%, ALT - 38.9\%). When the cumulative dose of MTX exceeded $3 \mathrm{~g}$, there was an increase in $\mathrm{Bl}$ and AST (Bl 37.5\%, AST 12.5\%) and a decrease in cholesterol and ALT (cholesterol 37.5\%, ALT 12.5\%). In the group of children not receiving MTX, $\beta$-lipoproteins increase was observed (66.7\%). A decrease was observed in groups with a total dose $<1 \mathrm{~g}(33.3 \%)$ and 1-3 $g(27.8 \%)$, and an increase of $43.7 \%$ was observed at a dose of more than $3 \mathrm{~g}$.

Thus, the risk of impaired liver function is still present, regardless of the increase in the MTX cumulative dose. The use of liver fibrosis indices is important for identification of children who need careful liver monitoring. The values of the indexes in accordance with the cumulative dose of MTX are shown in Tab. 2. APRI index values increase when the cumulative dose of MTX reaches $1 \mathrm{~g}$, and begin to decline again after exceeding 3 g. Statistically significant differences of the APRI index were found in groups of patients who did not receive MTX or received $<1 \mathrm{~g}(p=0.009)$. Significant differences in the APRI index were found between groups 3 and $4(p=0.042)$. There were no differences in the APRI index among other studied groups of adolescents with JIA.

There were no significant differences in the FIB- 4 score index between groups 1 and 2 of adolescents ( $p=0.218$ ) (Tab. 2). There was also no significant difference in the FIB-4 score index between groups 2 and $3(p=0.263)$. However, further analysis revealed a statistically significant difference in the FIB- 4 score precisely between groups 3 and 4 of adolescents receiving MTX $<3 \mathrm{~g}$ and $>3 \mathrm{~g}(p=0.023)$. That is, an increase in the FIB- 4 score is observed only when the cumulative dose 


\begin{tabular}{|c|c|c|c|c|c|}
\hline \multicolumn{2}{|c|}{ Patient's groups } & APRI & FIB-4 score & AAR & AARPRI \\
\hline 1 & $\begin{array}{c}\text { Did not receive MTX } \\
(n=18)\end{array}$ & $0.29 \pm 0.03$ & $0.24 \pm 0.03$ & $1.24 \pm 0.06$ & $0.73 \pm 0.04$ \\
\hline 2 & $\begin{array}{c}\text { MTX CD up to } 1 \mathrm{~g} \\
(n=15)\end{array}$ & $\begin{array}{l}0.43 \pm 0.03 \\
p=0.009\end{array}$ & $0.29 \pm 0.01$ & $1.21 \pm 0.06$ & $0.73 \pm 0.04$ \\
\hline 3 & $\begin{array}{l}\text { MTX CD 1-3g } \\
(n=18)\end{array}$ & $0.35 \pm 0.04$ & $0.28 \pm 0.02$ & $\begin{array}{l}1.05 \pm 0.05 \\
p=0.021\end{array}$ & $\begin{array}{c}0.62 \pm 0.02 \\
p=0.036\end{array}$ \\
\hline 4 & $\begin{array}{c}\text { MTX CD more than } 3 \mathrm{~g} \\
(n=17)\end{array}$ & $\begin{array}{c}0.325 \pm 0.03 \\
p=0.042\end{array}$ & $\begin{array}{c}0.323 \pm 0.02 \\
p=0.023\end{array}$ & $\begin{array}{c}1.072 \pm 0.07 \\
p=0.046\end{array}$ & $\begin{array}{c}0.645 \pm 0.05 \\
p=0.11\end{array}$ \\
\hline
\end{tabular}

Tab. 2. Index values according to MTX cumulative dose

exceeds $3 \mathrm{~g}$. The analysis of the results for the AAR index showed no significant differences within the groups both among adolescents not taking MTX and among those on MTX $<1 \mathrm{~g}(p=0.699)$. However, a significant difference was found between groups 2 and $3(p=0.021)$. Further analysis revealed a statistically significant difference in the AAR index between groups of adolescents who received MTX from 1 to $3 \mathrm{~g}$ and $>3 \mathrm{~g}(p=0.046)$. That is, in accordance with the AAR index, positive dynamics is observed.

The AARPRI index calculation demonstrated no significant differences within the groups, both among adolescents who received MTX up to $1 \mathrm{~g}$ and those who did not receive $\operatorname{MTX}(p=0.966)$. Changes are similar for groups 2 and 3 $(p=0.036)$. The difference between groups 3 and 4 , with MTX cumulative dose of 1-3 g and more than $3 \mathrm{~g}$, was not statistically significant $(p=0.111)$. That is, in accordance with the AARPRI index, a positive dynamics is observed.

\section{DISCUSSION}

Much attention should be paid to the screening methods for children with JIA treated with MTX.

Liver tests, as well as ALT level monitoring during JIA therapy is recommended ${ }^{(12)}$, but it does not fully reflect the state of the liver. In our study, we did not find significant elevations of $\mathrm{Bl}(\mu \mathrm{mol} / \mathrm{L})$, cholesterol $(\mathrm{mmol} / \mathrm{L}), \beta$-lipoproteins $(\mathrm{g} / \mathrm{L})$, AST $(\mathrm{U} / \mathrm{L})$, ALT $(\mathrm{U} / \mathrm{L})$ in all groups of patients. The use of indexes is a more convenient, cheap and non-invasive method to identify possible fibrotic changes, as also reported by other authors ${ }^{(10,14-18)}$.

Liver damage can significantly complicate JIA treatment with MTX; therefore, studies on non-invasive methods for the diagnosis and assessment of liver steatosis and fibrosis as prognostic factors seem to be promising. Despite many studies describing liver damage in JIA patients, we found no irreversible pathological changes in the liver, especially in the early stages of JIA treatment with MTX in paediatric practice, which were already discussed in some studies ${ }^{(6-9)}$. Thus, according to our observations, the risk of liver damage may be due to JIA, even before taking MTX. The risk of liver damage decreases with the onset of therapy, which is possibly associated with the antifibrotic effect of the drug and a decrease in the inflammatory process in both joints and the liver. However, long-term treatment with MTX may cause irreversible changes in the liver, which subsequently significantly aggravates the patient's quality of life and the effectiveness of the treatment of arthritis. In this study we analysed APRI, FIB-4 score, AAR and AARPRI indexes. JIA patients with a high cumulative dose of MTX should be carefully monitored for liver fibrosis ${ }^{(13)}$. Thus, according to our data, when studying the dynamics of non-invasive indexes, their heterogeneous nature and cumulative dose dependence are determined. We have identified a statistically significant probability and changes in indexes when children reach cumulative doses of MTX $1 \mathrm{~g}$ and $3 \mathrm{~g}$.

Our findings showed that the APRI index is the most significant $^{(25)}$. We believe that it is the APRI index that can be used for daily practice in paediatrics. It seems to be of particular importance for differentiating, based on screening methods, between patients at risk vs. those at no risk of steatosis and fibrosis. It is possible to monitor carefully liver function during the whole treatment and conduct a more in-depth examination only if it is necessary.

We are aware that the small sample size is a limitation of the study. Despite the fact that liver biopsy remains diagnostic standard, it is an invasive method and cannot be used to perform population screening and assess the course of the disease in patients with diagnosed steatosis or fibrosis. Therefore, liver biopsy was not performed, and we cannot definitively exclude liver fibrosis and steatosis. However, morphological study cannot be provided according to modern ethical standards. It cannot be used as a screening method in paediatrics. Our study included mostly adolescents with JIA treated with MTX without any other serious comorbidities, and our results should not be extrapolated to the general population. On the other hand, the strength of our study is that we recruited adolescences with JIA without other serious chronic diseases, with different cumulative doses of MTX.

\section{CONCLUSIONS}

1. According to our data, pathological changes in the liver in adolescents with JIA depend on MTX cumulative dose for the duration of the disease and are noted when the children reach a cumulative dose of $1 \mathrm{~g}$ and $3 \mathrm{~g}$ of MTX. 
2. According to our data, the most informative index was the APRI index, which can be used to detect early signs of liver fibrosis in patients with JIA on MTX.

\section{Conflict of interest}

The authors declare no conflict of interest in this article preparation.

\section{References}

1. Adriano LS, de França Fonteles MM, de Fátima Menezes Azevedo $\mathrm{M}$ et al.: Medication adherence in patients with juvenile idiopathic arthritis. Rev Bras Reumatol Engl Ed 2017; 57: 23-29.

2. Akioka S: [A better understanding of juvenile idiopathic arthritis with classification criteria]. Nihon Rinsho Meneki Gakkai Kaishi 2016; 39: 513-521.

3. Thierry S, Fautrel B, Lemelle I et al.: Prevalence and incidence of juvenile idiopathic arthritis: a systematic review. Joint Bone Spine 2014; 81: 112-117.

4. Petty RE, Southwood TR, Manners P et al.: International League of Associations for Rheumatology classification of juvenile idiopathic arthritis: second revision, Edmonton, 2001. J Rheumatol 2004; 31: 390-392.

5. Chhabra A, Oen K, Huber AM et al.: Real-world effectiveness of common treatment strategies for juvenile idiopathic arthritis: results from a Canadian cohort. Arthritis Care Res (Hoboken) 2020; 72: 897-906.

6. Hiraga Y, Yuhki Y, Itoh K et al.: Pharmacokinetics and efficacy of low-dose methotrexate in patients with rheumatoid arthritis. Mod Rheumatol 2004; 14: 135-142.

7. Ravelli A, Di Fuccia G, Molinaro M et al.: Plasma levels after oral methotrexate in children with juvenile rheumatoid arthritis. J Rheumatol 1993; 20: 1573-1577.

8. Hornung N, Ellingsen T, Attermann J et al.: Patients with rheumatoid arthritis treated with methotrexate (MTX): concentrations of steady-state erythrocyte MTX correlate to plasma concentrations and clinical efficacy. J Rheumatol 2008; 35: 1709-1715.

9. Dalrymple JM, Stamp LK, O’Donnell JL et al.: Pharmacokinetics of oral methotrexate in patients with rheumatoid arthritis. Arthritis Rheum 2008; 58: 3299-3308.

10. Ratziu V, Bellentani S, Cortez-Pinto $\mathrm{H}$ et al.: A position statement on NAFLD/NASH based on the EASL 2009 special conference. J Hepatol 2010; 53: 372-384.

11. Miller MH, Ferguson MAJ, Dillon JF: Systematic review of performance of non-invasive biomarkers in the evaluation of nonalcoholic fatty liver disease. Liver Int 2011; 31: 461-473.

12. Karlsson Sundbaum J, Eriksson N, Hallberg P et al.: Methotrexate treatment in rheumatoid arthritis and elevated liver enzymes: a long-term follow-up of predictors, surveillance, and outcome in clinical practice. Int J Rheum Dis 2019; 22: 1226-1232.

13. Lertnawapan $R$, Chonprasertsuk $S$, Siramolpiwat S: Association between cumulative methotrexate dose, non-invasive scoring system and hepatic fibrosis detected by Fibroscan in rheumatoid arthritis patients receiving methotrexate. Int J Rheum Dis 2019; 22: $214-221$.

14. Mushtaq S, Ghani E, Azam K et al.: Comparison of chitinase3-like protein 1, aspartate aminotransferase-to-platelet ratio index, and fibrosis-4 index with shear-wave elastography. Eur J Gastroenterol Hepatol 2019; 31: 357-362.

15. Golabi P, Paik J, Hwang JP et al.: Prevalence and outcomes of non-alcoholic fatty liver disease (NAFLD) among Asian American adults in the United States. Liver Int 2019; 39: 748-757.

16. Kumar A, Vasdev V, Manrai M et al.: Assessment of hepatic fibrosis in patients with rheumatoid arthritis on long-term methotrexate therapy using transient elastography. Indian J Rheumatol 2018; 13: 246-251.

17. Kim SU, Kim BK, Park JY et al.: Fibrosis-4 index at diagnosis can predict all-cause mortality in patients with rheumatoid arthritis: a retrospective monocentric study. Mod Rheumatol 2020; 30: 70-77.

18. Sha FR, Pk MU, Abuelezz NZ et al.: Investigating the efficiency of APRI, FIB-4, AAR and AARPRI as noninvasive markers for predicting hepatic fibrosis in chronic hepatitis B patients in Bangladesh. The Open Microbiology Journal 2019; 13: 34-40.

19. Castéra L, Vergniol J, Foucher J et al.: Prospective comparison of transient elastography, Fibrotest, APRI, and liver biopsy for the assessment of fibrosis in chronic hepatitis C. Gastroenterology 2005; 128: 343-350.

20. Ferraioli G, Tinelli C, Malfitano A et al.: Performance of realtime strain elastography, transient elastography, and aspartateto-platelet ratio index in the assessment of fibrosis in chronic hepatitis C. AJR Am J Roentgenol 2012; 199: 19-25.

21. Barbero-Villares A, Mendoza J, Trapero-Marugan $M$ et al.: Evaluation of liver fibrosis by transient elastography in methotrexate treated patients. Med Clin (Barc) 2011; 137: 637-639.

22. Shomuradova SS, Alimov AV: [Condition of hepatobiliary system in juvenile rheumatoid arthritis]. Eksp Klin Gastroenterol 2016; (7): 38-42.

23. Arena U, Stasi C, Mannoni A et al.: Liver stiffness correlates with methotrexate cumulative dose in patients with rheumatoid arthritis. Dig Liver Dis 2012; 44: 149-153.

24. Park SH, Choe JY, Kim SK: Assessment of liver fibrosis by transient elastography in rheumatoid arthritis patients treated with methotrexate. Joint Bone Spine 2010; 77: 588-592.

25. Wai CT, Greenson JK, Fontana RJ et al.: A simple noninvasive index can predict both significant fibrosis and cirrhosis in patients with chronic hepatitis C. Hepatology 2003; 38: 518-526.

26. Kim BK, Kim DY, Park JY et al.: Validation of FIB- 4 and comparison with other simple noninvasive indices for predicting liver fibrosis and cirrhosis in hepatitis B virus-infected patients. Liver Int 2010; 30: 546-553.

27. Sheth SG, Flamm SL, Gordon FD et al.: AST/ALT ratio predicts cirrhosis in patients with chronic hepatitis $\mathrm{C}$ virus infection. Am J Gastroenterol 1998; 93: 44-48.

28. Shoaei SD, Sali S, Karamipour M et al.: Non-invasive histologic markers of liver disease in patients with chronic hepatitis B. Hepat Mon 2014; 14: e14228. 